\title{
Field notes
}

\section{On choosing the place.}

\section{The open Wiccan rituals in the city of Warsaw}

\section{Joanna Malita-Król}

This is the original, accepted paper. The final version of the article was published in the Nova Religio (2021) 25 (1): 108-121.

https://doi.org/10.1525/nr.2021.25.1.108

\begin{abstract}
Numerous contemporary Pagan groups conduct their ritual ceremonies outside, communing with nature. The following essay describes my research in a small, eclectic group following the Wiccan wheel of the year in Warsaw, Poland. I focus on the places used by the group, applying Edward Casey's phenomenological approach to understand an encountered place. Three locations are presented, each of them in the bosom of nature, yet within the city borders. I particularly examine what constitutes a good ritual place according to the group members. My initial supposition was that technical aspects would prevail: privacy, accessibility and proximity of the four elements. However, the participant observation and semi-structured interviews proved that the main reason behind choosing the right place was based on the experience and the interpretation of the feeling evoked by the place: namely, whether the atmosphere was right and the entities dwelling there were seen as welcoming or not.
\end{abstract}

KEYWORDS: Wicca, ritual, Poland, phenomenological approach, sacred space

One of the aims of the contemporary Pagan ritual practice is to connect and commune with nature, be it during group rituals or within a private ritual framework. Some can use secluded countryside as their place of worship, whereas others need to find something in the city. As the process of finding a proper place - connected to nature, yet located within the city borders - seemed very interesting, I decided to explore it during my field research, while 
conducting participant observation in a small, eclectic group following the Wiccan wheel of the year rituals in Warsaw, the capital of Poland.

Presently, the Neopagan community in Poland consists mostly of the followers of Native Faith movement ("rodzimowierstwo," also translated as "Rodnovery"), reconstructing religious praxes of pre-Christian Slavs. As for the numbers, the last national census from 2011 estimated the amount of adherents of "Paganism (Native Faith) and Neopaganism" to around 900 people, ${ }^{1}$ a tiny minority within the landscape dominated by Roman Catholicism. The number of people following Pagan paths has definitely grown since 2011 and can be safely estimated to at least a couple thousand as of 2020. In the context of the group I studied, Wicca seems to be the most important point of reference. This particular religion arrived in Poland in mid 1990s, along with other "imported" Neopagan religions, such as Ásatrú. The initial stages of Wicca's development were related to the expansion of the internet ${ }^{2}$ and only at the beginning of 21 st century was Traditional Wicca ${ }^{3}$ introduced, when first Poles were initiated abroad and later established their own covens in Poland. The numbers of initiations has been growing, as well as the number of people who simply wanted to become more familiar with Wiccan practice, but not necessarily go through the initiation ritual themselves. Still, the Wiccan community in Poland remains relatively small - a few dozen initiated into traditional covens during my field research in years 2014-2018.

I took part in studied group rituals since Samhain in November 2015 until Autumn Equinox in September 2018 (twelve rituals altogether), while conducting participant observation for my $\mathrm{PhD}$ thesis dedicated to Polish Traditional Wiccans. ${ }^{4}$ I performed active role in every single ceremony I was present at, from blessing the salt and water to greeting the elements. I also invited the chosen gods, prepared ritual cookies and brought other necessary artefacts (including wine or altar decorations). In addition, I conducted four semi-structured interviews with those group members, who at the time of the interview constituted the core of the group. The interviews were recorded and later transcribed (by myself, as I assured my interviewees that it will be so) and compose the basis of my sources along with my field diary, ritual scenarios distributed by the organizers and photographs taken on the spot.

The aim of this field notes essay is to present the group I studied, its rites and the locations chosen to conduct the ceremonies. I specifically analyze the places in which the ritual circle was cast: what they looked like, what their specific location was, and why they were actually chosen. My initial supposition was that the key reason to choose the place was 
its 'technical' merits - namely, being reachable, yet isolated, and in closeness to four elements (earth, fire, water, and air) which play a vital role in Wiccan rituals. However, my research, especially the interviews, showed that the reason was eventually based on the metaphysical interpretations of the feeling a certain place evoked - whether the spirits and the energies of the place were seen as welcoming or not.

Those interpretations and experiences of the interviewees lead us straight to the phenomenological approach to sacred space, which turns attention to yet another participant of the ritual - the place itself, with all its particularities. This means that from the believer's point of view, sacred sites can actually speak with their own voice and emanate mysterious power which draws people to them. This perspective is represented by more ecologicallyoriented scholars, among them psychologist James Gibson with his theory of affordances ${ }^{5}$ and philosopher Edward S. Casey. According to the latter, there are six different yet essential features or "moments" in the exchange between the embodied subject and a perceived landscape. Historian of religion Belden C. Lane summarizes them accordingly: 6

1. "Surrounding array" - the general ambient of the place.

2. "Sensuous surface" - the aspect of the array which stands out on the first encounter.

3. "Things" - physical objects profiled on the sensuous surface (like trees or rocks).

4. "Ground" - the extension of the surface downwards, underfoot and deeper.

5. "Arc" - an exhibiting curvature, less constricted than the horizon.

6. "Atmosphere" - the embodiment of the "tonality" of the place. ${ }^{7}$

The very last feature, the atmosphere, seems to be fundamental in understanding the narrations of my interviewees. Casey considers it the most pervasive of all the features, as it permeates everything else, and compares it to Martin Heidegger's Befindlichkeit, "moodwise situatedness". ${ }^{8}$ While we are in a certain place, Casey explains, "we sense it not only continuous with our own feeling - or as reflecting that feeling - but also as itself containing feeling". ${ }^{9}$ Thus, a place possess a feeling of its own which can be and is discovered by those who enter it.

In the context of this essay this means that some particular precognitive assumptions led to choosing and approving the location on the basis of this very "feeling" and atmosphere, attributed by the interviewees - as we will observe - to some specific other-than-human entities. Interestingly, this also means that a double place-defining process has happened: first the location for the ritual was chosen on the basis on metaphysical interpretation of the feeling 
a certain place evokes. Secondly, the ritual circle was constructed in that very location on the spot, isolating the space by the hand of acting High Priestess. Referring back to Gerald Gardner (1884-1964), the man without whom today's Traditional Wicca would not come to being - the circle is supposed to keep the energy risen by the participants inside the circle and remains to be between this world and the dominion of gods. ${ }^{10}$ Thus, a circle becomes a very unique meeting place and a kind of 'safe bubble,' in which the participants of the ritual can meet their gods and practice magic.

\section{THE STUDIED GROUP}

The group I studied is not a traditional Wiccan coven, yet at first it was connected to one of the Polish Traditional Wiccan milieus, the online forum Wiccański Krąg (literally, "Wiccan Circle," coordinated by Wiccans from the Whitecroft line ${ }^{11}$ ). In the beginning, the rituals were even more open (with dates and meeting places announced online), but as time passed, a more or less permanent composition of members has developed, around a dozen people. The members started to organize themselves mostly through emails, a Facebook group dedicated to organizational issues functioned for a few months as well. ${ }^{12}$ The group was referred to simply as "our (ritual) group" (in Polish: "nasza grupa (obrzędowa)") and never received any proper name.

Initially, the course of rituals was based on Wiccan wheel of the year, with some later additions as the group developed. This meant celebrating eight annual festivals, called "sabbats," ("sabaty" in Polish) connected to solar and cycle and seasonal transition: Samhain, Winter Solstice (Yule), Imbolc, Spring Equinox, Beltaine, Summer Solstice, Lammas (Lughnasad) and Autumn Equinox, which happen at six weeks intervals. ${ }^{13}$ Later, the festivals were referred to in both Wiccan and Native Faith terminology - for example, Summer Solstice was called "Kupała" as well (Kupała is a rendition of Midsummer Eve), Autumn Equinox was referred to as "Plony" (literally, "Crops," a harvest festival) and Samhain's additional name was "Dziady" (understood as Slavic festival of the dead).

The first ritual, still under the auspices of Wiccański Krąg, was held in March 2015 and proposed by Sheila, an initiated High Priestess of a coven within the Whitecroft line. As she wrote in the invitation published on the forum of Wiccański Krąg: 
Our ritual will be based on the Wiccan one, so I will try to prepare it in such a way that everyone will have their own role - even a very small one - as it is done during our own, closed rituals. No one will be excluded, because everyone creates the ritual together. ${ }^{14}$

Therefore, since this very first ritual it has become customary that every participant performs even a smallest role: for example, greeting one of the elements. All participants were also expected to take part in ritual preparation, which I describe below.

The group consisted of only Polish people, mostly women and usually there were around ten people present at the ceremony (seven-eight women and two-three men, however, the core of the group was composed of women: my interviewees). Most of the members lived in the city, mainly in Warsaw or its outskirts, yet sometimes guests from other cities were present as well (with myself as a perfect example, as I needed to travel 300 kilometers from Kraków to every single ritual). The age of the participants can be estimated from 20 to 50 years and their professional career varied: students, freelancers, entrepreneurs, physical workers and others. The spiritual background and needs of the members varied as well: a few were simply exploring and searching for something which would suit their religious needs; a few were already following paths other than Wicca or witchcraft, but joined the rituals nonetheless (like Laszka, a Native Faith follower and the later leader of the group). Some people would take part in the rituals of the group, but then join a traditional Wiccan coven and become initiated. During my research two female participants undertook the training in a Wiccan coven and they were advised by the leaders of that coven to refrain from participating in the group rituals.

The group's initial character can be described as similar to Traditional Wicca - which means that there was a female leader ${ }^{15}$ who was responsible for the ritual in both logistic and spiritual aspects. She was the one to inform about the date of the rituals, send the invitation, enlist all the necessary artefacts to be brought by the participants, lead everyone from the meeting place to the actual ritual place and be the general conductor of all the preparations. She was also the one to conduct the ritual, cast the circle and invite the gods - namely, fulfilling tasks usually done by the High Priestess. This role was at first dedicated to Sheila, the aforementioned initiator of the group itself, then, since 2016, a Native Faith follower known as Laszka. By the end of 2017 the rituals became "less Wiccan:" firstly, the group refrained from instituting a male priest who would perform the core of the rituals with the serving High Priestess - symbolic unification of the male and the female, the God and the Goddess, represented by athame and a chalice of wine (this is a very Wiccan element and was 
treated by the members of the group as $\operatorname{such}^{16}$ ). Secondly, every participant, apart from performing a previously established role, was supposed to invite one chosen deity, suitable for the occasion and to which a given person felt particular connection. For example, for the ritual of Imbolc - a festival celebrating the light and commemorating the gods' coming out from the underworld - the group members invited, among other, Weles (Slavic god of magic, connected to the beyond), Brigid (Celtic goddess of fire), Inanna (chief goddess of the Mesopotamian pantheon) and Amaterasu (the Japanese Sun goddess). ${ }^{17}$ After Spring Equinox in March 2019 Laszka resigned from the role of the organizer; the group still celebrates every sabbat, if possible, but with no specific leader.

To give the idea of the course of rituals, I will briefly describe a ceremony organized for Samhain on November 2016. The group members met at a tram stop nearby and went together to the chosen area. There the place needed to be prepared, which meant picking up rubbish, collecting firewood, lighting a bonfire in the center of the planned circle and placing the altar (a piece of cloth spread on the ground on the north side of the circle with all the necessary ritual tools: ritual knife, athame, pentacle, bowls with water and salt, figures of God and Goddess, chalice with wine and a plate with cakes). Next, all the participants gathered beyond the planned circle and the rite was ready to commence.

Firstly, the ritual space was purified with symbolical sweeping of the broom, sprinkling the perimeter with water consecrated by salt and censing the planned circle (three group members were designated to those tasks). Then the others entered the ritual area, purifying themselves by a sprinkle of water and a little bit of the censer smoke. Everyone took their previously chosen places - it is worth noticing that during the ritual, in the circle, one should follow the sunrise or clockwise direction (also known as deosil). ${ }^{18}$ Then, the acting High Priestess (in this case, Laszka) cast the circle "in the name of the Horned Lord of the Woods and the Lady of the Moon" while walking behind the backs of the other ritual participants. She was holding a ritual knife, athame, and reciting a proper invocation. ${ }^{19}$ It was followed by an opening prayer, delivered by another person, who introduced all others to the theme of the celebrated festival, noted the time of the year and the aim of the ritual (in case of Samhain the longer nights were mentioned and that the God and the Goddess are currently beyond this world, dwelling in the underworld). Then, the elements were invoked: Air on the east, Fire on the south, Water on the west and Earth on the north. Every element was invoked by another group member who stood facing the right direction and delivered the welcoming with a bow. After the elements, the spirits of the place (Pol. "duchy miejsca") were welcomed 
as well, namely, the spirits of the forest, earth, the surrounding area as a whole - sometimes special spirits are greeted, like the Mermaid of Warsaw (Pol. "warszawska Syrenka"), a legendary creature and a symbol of the city, ${ }^{20}$ or the "idolaters" (Pol. "bałwochwalcy", soldiers of unknown Pagan faith buried in Golędzinów, see below). The deities were the last entity to be invited and welcomed: Laszka invited gods regarded as more dark and connected to the underworld: Hecate, Hades, Persephone.

The core of Samhain ritual was a meeting with the beloved departed - a very touching and moving moment, I must admit. Each ritual participant could share some wine (pouring it to the bonfire) with a certain departed, saying a few words about them. Additionally, Sheila conducted a brief pathworking ${ }^{21}$ during which the group members were allowed to meet their dead ancestors and other close people in a mist surrounding the circle. Then it was time for the ceremony of cakes and wine, when acting High Priestess with a male partner blessed cakes (by making a sign of pentagram above the cakes) and wine in the chalice (by dipping the tip of athame in wine). The chalice and the plate with cake were later distributed among the ritual participants - each of them took a sip of wine and a piece of cake and passed the chalice and the plate to a person next to him or her. This was a sign that the ritual is about to be over, a relaxing moment and an opportunity to discuss the experienced emotions. The official ending of the ritual was started by a closing prayer, a sort of summing up of the whole ritual and a request for a blessing from the gods. Then, it was the time to bid farewell to the elements with a few words and a bow. The circle was not "uncast," as it was thought that it would disperse on its own after saying goodbye to the elements. It was not customary to bid farewell to the gods or the spirits, either. The whole ceremony lasted around 40 minutes - it was the typical length of all the rituals of the group. In the Samhain festival, an additional ending was included: all the participants went to light a candle at the monument of the “idolaters." At the very end, there was a short feast - more wine, cakes and other goodies provided by all group members.

\section{THE RITUAL PLACES}

In contemporary Paganism and Witchcraft performing rituals outside the closed walls is considered as particularly important. 21st century Pagan temples are rarely erected, and outdoors seems to be the most natural (!) environment to search for a place for the ceremony. According to Vivianne Crowley, modern Pagans "seek to worship (...) beneath trees, sky, sun, 
moon and stars, by the sound of rushing water, ever-flowing sea, wind and the cry of the birds". ${ }^{22}$ In emic literature one can find a proper amount of suggestions, considering finding a suitable place where the ritual will be held. For example, Marion Green recommends a place where two or more elements can be found: "Anywhere where two elements meet (...) provides a sacred interface. Most of these are obvious outdoor locations like the edges of the sea and land, high in the hill, near lakes or waterfalls." 23

During my research, the ritual circle was cast in three outdoor locations. All of them were situated at the meeting point of at least two elements, however, this eventually turned out to be not of a vital importance to the studied group. The first location was a part of Warsaw called Golędzinów, nearby the railway embankment and the former cemetery of the cholera victims (it will be referred to as Golędzinów). A hardly accessible area was located between three railway embankments, with bushes and small trees growing here and there. A few birch trees formed a small circle which seemed perfect for ritual occasions. However, Golędzinów was used only for the Samhain/Dziady celebrations, that is, the ceremonies connected to the dead. The geographical context was very appropriate indeed, not only because there used to be a cemetery nearby (presently only a small monument honoring the victims of the epidemic ${ }^{24}$ ), but also due to the fact that on that very cemetery seven soldiers referred to as "idolaters" were once buried. According to Laszka, they were adherents of an unknown Pagan religion who fell during warfare centuries ago - although we have no specific information nor historical records considering who they were and what they believed in. Nonetheless, during rituals held at Golędzinów those soldiers were greeted among the spirits of the place.

The second ritual location was located on the eastern bank of the Vistula river, in a small riparian forest nearby the National Stadium and Świętokrzyski Bridge, on the opposite side to the famous monument of the Mermaid of Warsaw in Powiśle ${ }^{25}$ (it will be referred to as Mermaid's place). This river area is a site of Natura 2000 project, protected by the regulations of the European Union, similar to nature reserves, yet more approachable. ${ }^{26}$ It is used by the city residents for walks and even fishing, as the eastern bank seems to more be more "wild" and less frequented than the western one, with mostly concrete boulevards, where a lot of pubs and restaurants. Some rituals took place in the forest itself, others at the very bank of the river, either on the left or the right side of the bridge. During one of the rituals a boar passed by a ritual circle which was recognized as a very fortunate sign by the group. The Mermaid's place was used at first due to its vicinity to the city center and relatively simple access - it was 
easy to find, especially for the late-comers and people who were not familiar with Warsaw's surroundings. In this particular place, the water in the Vistula river - greeted as an element at the beginning of the ritual - was located on the west, and the group considered it a very accurate opportunity.

The third ritual location, called Gwiaździsta, was situated on the bank of the Vistula river as well, but on the western side, farther from the city center. It was located very close to the Bielański Forest, also a part of Natura 2000 site, more secluded and wild, with mostly well-trodden paths. The group used to meet at the bus terminal called Gwiaździsta, hence the name. Two actual ritual places were used within this area, both very close to the river: one in a very small clearing near an embankment, one on the very bank, grown over with grass. At the first one, a small clearing, there was a big fallen tree trunk, used to set up the altar. In other places, where no such trunk was available, the altar was set up directly on the ground. Here, the river was flowing on the east, which now and then caused some confusion during establishing the ritual circle - in which the element of water is greeted on the west.

All the locations were found and proposed by Laszka, Varsovian born and bred. "I just know the city," ${ }^{27}$ she told me when I asked about the finding. She also performs rites with other groups, mainly Native Faith ones, thus she was able to discover various parts of Warsaw suitable for contemporary Pagan ceremonies. Apart from those three used by the studied group, Laszka mentioned for example the forest in the Bemowo, district located in the western part of Warsaw - although she described this very area as a bit too crowded. The Bemowo area would not be suitable for the group I studied, Laszka said, because its rites are based on the presence of the four elements. The Vistula does not run near the Bemowo forest - "[For this ritual group] I chose places by the riverside to have all the elements with myself," 28 she explained.

\section{WHY THIS PLACE? - THE INTERVIEWS}

During my research, apart from the participant observation, I decided to ask other group members about the right way of finding a proper place for the ritual. After obtaining an approval from the group to conduct my conversations after the ceremony, I interviewed all the group members present at this particular ritual - Beltane, the festival of love, when, according to the Wiccan wheel of year, the God and Goddess celebrate their matrimony. ${ }^{29}$ On a sunny Sunday at the beginning of May, after the ritual at the Gwiaździsta, in a merry atmosphere 
after celebrating love and all the possible positive emotions, I talked to four women - Laszka, Ula, Xen and a solitary witch who preferred to stay anonymous - who composed the core of the group at the time. My initial hypothesis was that their answers would center around logistical issues and geographic considerations related to the four elements, similarly to the aforementioned insights from the emic literature. However, all of my interviewees voiced very different explanations - they referred to their worldview which included respecting energies, spirits, entities inhabiting the chosen location and adding to the atmosphere of the very place.

Although the organizational theme was present in their answers, the emotions evoked by the location were the most significant feature of the ritual place. A certain "feeling", interpreted as a spiritual connection and approval of the entities who dwelled in the particular place turned out to be of the utmost importance. As put by one of the interviewees:

\footnotetext{
You simply feel that. (...) This place has its own power, its own charm. First of all, we are surrounded by greenery, there is some wind through this clearing, and water, and fire we kindle, and of course the earth we stand on. It cannot be described [in other words], you just feel it. ${ }^{30}$
}

Similar view was expressed by Xen who underlined that a proper feeling is a must. She mentioned that such a feeling accompanied her recently when she was buying a garden lot: "I entered it and shoot! This is it! I want it!." 31 This feeling, I was told, can be connected to the spirits of the place (aforementioned "duchy miejsca"). Laszka termed them as a "specific, private entities dwelling in the place." 32 If a place consists of a forest and some water - river or a lake - there would be spirits of forest and water. Some spirits are more 'famous' then the others, among them, the Mermaid of Warsaw, greeted during rituals in the Mermaid's place. Furthermore, some spirits, according to group members, are more welcoming then the others and this contributes to the feeling evoked by the place. According to Ula:

\footnotetext{
There are places in which some special spirits or energies can appear and they can influence our decisions on choosing the place. (...) And a witch has a sort of antenna, which detects such places and [when she finds one, she thinks] "Hmm, here it's fine." 33
}

While all five of us kept on discussing about how a place is found and detected, Laszka proposed a reverse interpretation - it is not the witch who chooses the place. It is the place which chooses the witch, namely, it feel special and sacred before any ritual occurred. "You keep walking... you reach a place... and you know, that it’s here," ${ }^{34}$ Laszka said. The 
quality of the ritual can become an indicator of whether the place is good or not: if the energy of the ritual is not right, if the fire continues to die down, if the atmosphere is simply not as it should be - this means that the place has been chosen wrongly and the spirits are not welcoming, feeling offended for not being greeted adequately. This is why, Laszka explained, one should always be kind to the place and its spirits, greet them respectfully and leave some small offering during or after the rite. "When you enter someone's house, you say 'good morning' politely and for the ritual place it works just the same," she said. The Gwiaździsta place and its spirits, in which the conversation above was recorded, received the ritual group favorably according to my interviewees: the energy of the rites was good and even the needed amount of firewood was easy to find.

\section{CONCLUSIONS}

My initial supposition was that the explanations considering the choosing of the place would center around organizational issues only. However, explanations provided by the interviewed members of the studied group were related rather to a "feeling" evoked by a particular place of ritual, the all-pervasive "atmosphere", in the terms of Edward Casey. Of course, physical aspects - isolated but still within the city borders, in the bosom of nature and located at the brink of at least two elements - were considered important as well, nevertheless the primary motive was the metaphysical understanding of the chosen space. To be precise, I would argue that those physical characteristics allowed to circle (!) a certain area of interest, but the ritual place was chosen because of the feeling it evoked. As far as the research material is concerned, I cannot say whether this was the actual motive and not the story the group told itself afterwards. However, I follow here the steps of ethnographist Jeanne FavretSaada who stated that "the native is always right, if he leads the investigator in unexpected directions" ${ }^{35}$ (a general precept of British anthropology, see the works of Edward EvansPritchard $\left.^{36}\right)$.

The feeling brought up by the interviewees of the studied group was interpreted in metaphysical terms, connected to the welcoming spirits of the given place or energies thought to be present there. All of the group members agreed to a certain location, because it felt appropriate for them for a few reasons. This means that those particular ritual places did not become sacred by the ritual itself, as they "spoke" to the participants before any celebrations actually happened. This contradicts the idea of a place being constructed by human ideas and actions, by a mindset imprinted in the ritual - represented by, among others, the theory of 
Jonathan Z. Smith ("ritual is not a response 'to the sacred'; rather, something or someone is made sacred by ritual", he writes in To Take Place). ${ }^{37}$ In the case of studied group the contrary happened: in the terms of choosing the location, the ritual was an answer to the place and the energy within the ritual circle depended on its atmosphere.

Joanna Malita-Król, Institute for the Study of Religions, Jagiellonian University in Kraków, j.malita-krol@uj.edu.pl

\section{ENDNOTES}

1 "Struktura narodowo-etniczna, językowa i wyznaniowa ludności Polski - NSP 2011," Główny Urząd Statystyczny, 10 December 2015, http://stat.gov.pl/spisy-powszechne/nsp-2011/nsp-2011-wyniki/strukturanarodowo-etniczna-jezykowa-i-wyznaniowa-ludnosci-polski-nsp-2011,22,1.html, accessed 11 September 2019. The latest statistical source from 2018 considering churches and religious associations included only five religious organisations termed as "Paganism and Neopaganism". Paweł Ciecieląg, Wyznania religijne w Polsce 2012-2014 (Warszawa: Główny Urząd Statystyczny), 28.

2 Joanna Malita, „Wicca w polskim Internecie - raport z badań terenowych.” Studia Religiologica. Zeszyty Naukowe Uniwersytetu Jagiellońskiego 49 (2016): 263-276, available at http://www.ejournals.eu/StudiaReligiologica/Tom-49-2016/Numer-49-3-2016/art/7958/, accessed 11 September 2019.

3 That is, those Wiccan traditions which date back to either Gerald Gardner or Alex Sanders.

${ }^{4}$ I have conducted field research among Polish Traditional Wiccans in years 2014-2016 (participant observation combined with semi-structured interviews) within the methodological framework of lived religion, exploring what being a Wiccan actually meant for my interviewees. I have recorded interviews with 31 persons (16 women and 15 men) who constituted around half of the all Polish Traditional Wiccan milieu at the time.

5 "Affordance" is a term coined by Gibson: "The affordances of the environment are what it offers the animal, what it provides or furnishes, either for good or ill.” James J. Gibson, The Ecological Approach to Visual

Perception: Classic Edition (New York and London: Psychology Press of Taylor\&Francis, 2015), 119.

${ }^{6}$ Belden C. Lane, "Giving Voice to Place: Three Models for Understanding American Sacred Space.” Religion and American Culture: A Journal of Interpretation 11 (2001), $70 \mathrm{f}$.

${ }^{7}$ See more in Edward S. Casey, Getting Back into Place: Toward a Renewed Understanding of the Place-World (Bloomington: Indiana University Press, 1993), 207-222.

8 Translated also as "attunement" or "state of mind". See Martin Heidegger, Being and Time, trans. by Joan Stambaugh (Albany: SUNY Press), xxv.

${ }^{9}$ Edward S. Casey, Getting Back into Place, 219.

${ }^{10}$ Gerald B. Gardner, Witchcraft Today (New York: Citadel Press, 2004), 26.

${ }^{11}$ Whitecroft line was founded by Eleanor Bone and its Polish members descend from the coven of Vivianne Crowley. See "Wiccański Krąg. O nas,” http://wiccanski-krag.com/o-nas/, accessed 17 September 2019.

${ }^{12}$ A group called "Obrzędy wiccańskiego koła roku," lit. "Rites of a Wiccan Wheel of the Year," established in February 2017, https://www.facebook.com/groups/1837111979881131/, accessed 11 September 2019.

${ }^{13}$ On the wheel of the year in Neopagan praxis in general, see e.g. Jenny Butler, "The Neo-Pagan Ritual Year and Historical Reinterpretations," in The Ritual Year and History (Ritual Year 3), ed. Irina Sedakova (Stráznice: Narodní ústav lidové kultury, 2008), 72-78. The wheel of the year in strictly Wiccan practice is described in 
emic literature, e.g. Stewart Farrar and Jane Farrar, A Witches' Bible. The Complete Witches Handbook. Part 1: The Sabbats and Rites for Birth, Marriage and Death (Marlborough: Robert Hale Limited, 1997), p. 13ff. Vivianne Crowley describes the mythical story behind the celebrations in her Wicca. A Comprehensive Guide to the Old Religion in the Modern World (London: Element, 2003), 157ff.

14 See thread "Równonoc Wiosenna w Warszawie," http://forum.wiccanskikrag.com/viewtopic.php?f=44\&t=1012, accessed 25 May 2017. All the quotations are translated by myself.

${ }^{15}$ A High Priestess in Wiccan coven is usually "the female leader and overall leader." Farrar and Farrar, $A$ Witches' Bible. Part 2, 322.

${ }^{16}$ In British Traditional Wicca, the polarity of male and female is heavily stressed and both principles, though very much different from each other, are of equal importance. According to Gerald Gardner, "to the witch the God and the Goddess are the Male and Female, the Right and the Left, the Two Pillars which support the Universe." Gerald Gardner, The Meaning of Witchcraft (New York: Magickal Childe, 1982), 127.

${ }^{17}$ Field note from open ritual at Imbolc (Warsaw, 31 January 2018).

${ }^{18}$ The direction against the sun, anti-clockwise is called widdershins. See Farrar and Farrar, A Witches' Bible. Part 2, 322-328.

${ }^{19}$ I have the whole ritual scenario and all the suggested invocations in my archives, although I was asked not to publish those texts in any article.

${ }^{20}$ The Mermaid of Warsaw is a heroine of a few Polish legends. According to one of them, two mermaid sisters came to Europe from the Atlantic Ocean: one sister decided to stay in Copenhagen, the other traveled up the Vistula river and took a liking to the bank of Warsaw's Old City. She was such a gifted singer that even the fishermen did not harm her when she freed the fish from their nets. The Mermaid of Warsaw remains a symbol of the city, proudly posing in Warsaw's coat of arms since the 15th century. She is also represented in numerous monuments, mostly in the shape of half-women, half-fish. In the case of the studied group, she became a sort of "spiritual creature" of the ritual place located nearby the monument by the Wybrzeże Kościuszkowskie Street, on the bank of the Vistula river ("the Mermaid's place" in the article). For the history of the Mermaid and the legends, see e.g.: Anna Wajs and Magdalena Masłowska, "Syrenka niejedno ma imię," Stolica, October 2010, http://web.archive.org/web/20150923173441/http://www.archiwa.gov.pl/pl/component/content/article/36-mediao-nas/1949-1102010-r-stolica.html?template=archiwa_home, accessed 11 September 2019.

${ }^{21}$ In contemporary magical practice, pathworking usually denotes a guided meditation, during which one person reads a text describing some sort of a journey and the others visualize this journey while having their eyes closed. See e.g.: Yvonne Aburrow, "Visualisation, meditation, and pathworking," Patheos, 4 June 2014, https://www.patheos.com/blogs/sermonsfromthemound/2013/06/visualisation-meditation-and-pathworking/, accessed 11 September 2019.

${ }^{22}$ Vivianne Crowley, Phoenix from the Flame. Pagan Spirituality in the Western World (London: The Aquarian Press, 1994), 188.

${ }^{23}$ Marion Green, The Path Through the Labyrinth: The Quest for Initiation into the Western Mystery Tradition, (London: Element, 1988), 40.

24 "Cmentarz epidemiczny na Golędzinowie," http://sowa.website.pl/cmentarium/Cmentarze/CmWZ_2.html, accessed 11 September 2019.

${ }^{25}$ The monument, commissioned and funded by the city of Warsaw, was designed by Ludwika Nitschowa and erected in April 1938. To this day it remains on the same site: in Powiśle district, on Wybrzeże Kościuszkowskie street. See: Irena Grzesiuk-Olszewska, Warszawska rzeźba pomnikowa (Warszawa: Neriton, 2003), 100.

${ }^{26}$ Natura 2000 (lit. "Nature 2000") is a EU network of protected natural sites, both on land and sea, which ensures the survival of threatened species and habitats all across the European Union. Unlike the strict nature reserves, in Natura 2000 areas human activities are not excluded. See "Natura 2000," https://ec.europa.eu/environment/nature/natura2000, accessed 3 January 2020. For areas protected in Poland, including Warsaw, see “Obszary Natura 2000," http://natura2000.gdos.gov.pl, accessed 11 September 2019.

${ }^{27}$ Laszka (Warsaw, 6 May 2018).

${ }^{28}$ Laszka (Warsaw, 6 May 2018).

${ }^{29}$ Farrar and Farrar, $A$ Witches' Bible. Part 1, 80ff.

${ }^{30}$ A solitary witch (Warsaw, 6 May 2018).

${ }^{31}$ Xen (Warsaw, 6 May 2018). 
${ }^{32}$ Laszka (Warsaw, 6 May 2018).

${ }^{33}$ Ula (Warsaw, 6 May 2018).

${ }^{34}$ Laszka (Warsaw, 6 May 2018).

${ }^{35}$ Jeanne Favret-Saada, Deadly Words: Witchcraft in the Bocage, trans. Catherine Cullen (Cambridge: Cambridge University Press, 1980), 13.

${ }^{36}$ Edward Evans-Pritchard, "Some Reminiscences and Reflections on Fieldwork." Journal of the Anthropological Society of Oxford 4 (1973): 1-12.

${ }^{37}$ Jonathan Z. Smith, To take Place: Toward a Theory of Religion (Chicago: Chicago University Press, 1987), 105. See also: Catherine Bell, Ritual Theory, Ritual Practice (Oxford: Oxford University Press, 2009). 